\title{
CONSTITUTIONAL INTERPRETATION OF ORIGINAL INTENT ON FINDING THE MEANING OF SOCIAL JUSTICE IN THE CONSTITUTIONAL REVIEW
}

\author{
Agnes Harvelian ${ }^{1} ;$ Muchamad Ali Safa'at ${ }^{2 ;}$ Aan Eko Widiarto ${ }^{3}$;Indah Dwi Qurbani4 \\ 1,2,3,4Faculty of Law Universitas Brawijaya \\ Email: agnesharvelian@student.ub.ac.id¹; safaat@ub.ac.id², widiarto@ub.ac.id³; \\ indah.qurbani80@ub.ac.id ${ }^{4}$
}

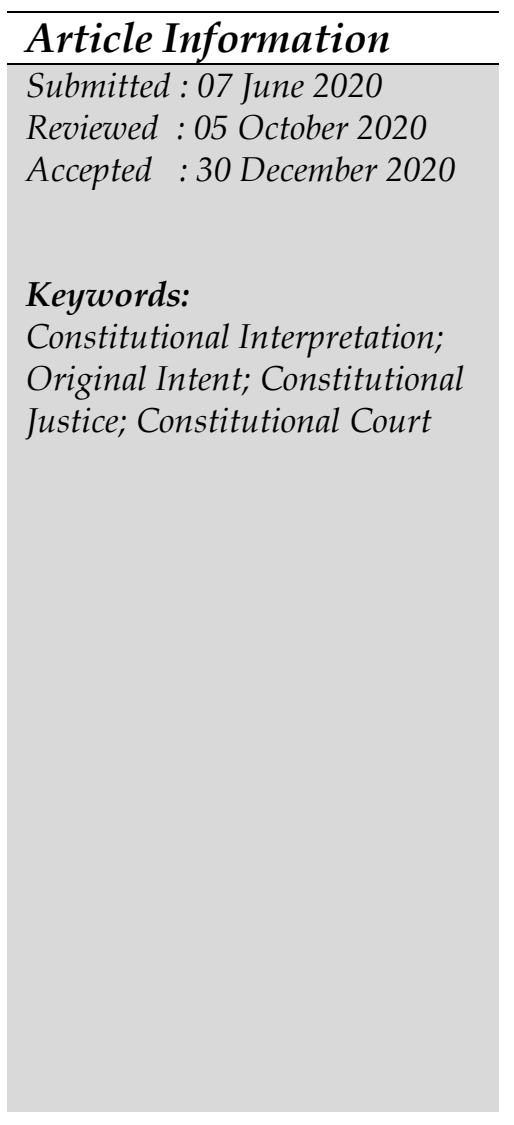

\begin{tabular}{l}
\hline Abstract \\
\hline This article will study whether original intent method able to find \\
justice in constitution and formulate constitutional interpretation \\
that will able to perform constitutional supremacy. This study uses \\
a doctrinal approach or also referred to as the normative legal \\
approach. The method taken in this writing is analysis descriptive \\
which describes and analyses constitutional interpretation with \\
original intent method. Formulating constitution interpretation \\
which answers people dynamic but doesn't lose its original \\
constitutional intent. This research shows that Constitutional \\
interpretation with original intent method can mean as an \\
interpretation which assimilate the spirit of how the original \\
written constitution was formulated when building UUD 1945, the \\
opinion of constitution's founders in their understanding on the \\
purpose and the nation's ground principals. Basically, All the rules \\
must not contradict with constitution's intention. The freedom of \\
judges to decide is not freedom without limits. The limitations of \\
judges' freedom of interpretation are Pancasila and the 1945 \\
Constitution. Decisions made by judges must not conflict with \\
Pancasila and the 1945 Constitution, constitutional judges have \\
great power in interpreting the 1945 Constitution. This power is \\
vulnerable to various interests which make the decisions of \\
constitutional judges not objective. Accountability of decisions in \\
public and academics should be a legal idea that can be realized, not \\
to judge the verdict but to know the basis of interpretation and or \\
legal discovery by constitutional judges.
\end{tabular}

\section{Introduction}

The development of constitution in the world divides into two groups which are constitution in the broad paradigm and the constitution in the narrow paradigm, the broadly one includes written and unwritten constitution, while the narrow one only covers the written constitution or the 1945 Constitution. CF. Strong emphasized that there is no constitution that is entirely unwritten nor that is entirely written (CF. Strong, 2012: 66).

Constitution can be literally translated as a basic norm that underlies formation of any inferior law. The constitution is a basic norm that contains the substantive principle of political morality that forms the basis of the legitimacy of 
law order (David Dyzenhaus, 2016: 10). Miriam Budiardjo believes that constitution is a charter that states the nation ideals and the basis of nation's state organization, in which there are various basic rules in relation to sovereignty, distribution of power of state institutions, ideas and state ideology, economic problems and so on (Miriam Budiardjo, 2008: 95). KC. Wheare argues that the constitution is the whole system of a country administration in the form of a regulations collecting that shape, regulate or govern a country (KC. Wheare, 2008: 1). The constitution is a collective agreement that contains ideal practice of running a country based on the philosophical beliefs of each nation to achieve its goals. The constitution comes with the aim to limit the power of the authorities, the concept of a constitutional state is adopted as basis for limiting the authority of the government, so that every state administration practice must be based on constitution as a joint resultant.

The Indonesian constitution, called the 1945 Constitution (UUD 1945), and after the amendment of its name was changed to the 1945 Constitution of the Republic of Indonesia (UUD NRI 1945). Prior to amendment, the 1945 Constitution consisted of Preamble, Body (16 Chapters, 37 Articles, 65 Paragraphs, 4 Article Transitional Rules and 2 Additional Regulations Paragraphs) and Explanations. Whereas after the amendment, the 1945 Constitution of the Republic of Indonesia consists of Preamle and Body (16 Chapters, 37 Articles, 194 Paragraphs, 3 Article Transitional Rules and 2 Additional Rules Paragraphs).

Hans Nawiasky said that Pancasila and also the Preamble of the 1945 Constitution can be considered as fundamental state norms which give meaning that the basic norms are shaped by legitimate state shaping instruments and within that constitution (Jimly Asshiddiqie, 2002: 10-11), the purpose of the state, the politics of the state, the philosophy of the state or the staatsidee (state ideals) that function as the "filosofische grondslag" and common platforms or common believes among fellow citizens in the context of national life.

Understanding the 1945 Constitution of the Republic of Indonesia as a basic norm which has become the source of all sources of law under it, requires a comprehensive understanding. Describing all articles into a formulation of legislation requires constitution interpretation which can lead to finding the meaning of justice in the constitution. Before amendment, the 1945 Constitution consisted of Preamble, Body and the Explanation, this arrangement, especially the explanation section, helped to interpret the constitution with the "original intent" method. The explanation section is the official (authentic) interpretation of the lawforming regulations. However, after the amendment, the 1945 Constitution of the Republic of Indonesia only consists of Preamble and Body.

Based on the theory of law formation, provisions in the Additional Rules Article II of the (Amended) 1945 Constitution do not necessarily eliminate the Explaination of the 1945 Constitution, because everything formulated in the 
Explanation of the 1945 Constitution is a unity with the Preamble and the Body of the 1945 Constitution. Even though on the People's Consultative Assembly agreement wants to eliminate the explanation section of the 1945 Constitution, but this matter is not stated explicitly (Maria Farida Indrati, 2019: 10).

Interpretation of the written constitution, whose main product is text, will make interpreting meaning of the text becomes the main method of interpretation. In constitution, the text is divided into two groups, namely the "syntactic constitution", A condition in which the constitution is being understood as a set of linguistic symbols that are not interpreted and "semantic constitution" which is a collection of meanings, taking into account the meaning of the constitutional text, so that the main idea of the constitution can be understood (Jose Juan Moreso, 1998: 131).

The constitutional text must be given its meaning through interpretation of its text first, as a way of understanding the intentions and it's intended objectives by the constitution-forming body. This "originalist" interpretation focuses on evaluating legal norms based on its original meaning or original intent. Interpretation of constitution using the original intent method is considered as an interpretation that goes into the initial spirit of the formation of the written constitution through the debate during the preparation of the 1945 Constitution, the opinions of the constitution-drafters related to an understanding of the directions and foundations of the state.

Framers of constitution, a view which argues that originalist sources included in previous writings when drafting the constitution, articles, newspapers, minutes (H. Jefferson Powel, 1980: 886) and trial notes in the formation of the 1945 Constitution.

Antonin Scalia, a Supreme Court Justice of the American Supreme Court, argues that interpretation of the constitution can only be done through an understanding approach from the constitution drafters themselves or a general understanding of the community towards the constitution (Saldi Isra, 2010: 58). The Originalists believe that the best way to interpret the constitution is to look at the goals of the constitution-builders. Based on the analysis research, the problem of this paper is Will interpreting of the constitution with the original intent able to find the meaning of justice in accordance to the constitution?; and How does Constitutional Justices independently formulate the interpretation of the constitution in judicial review?

The explanation above, serves author's background to analyse and present novelty in relation to the study of the extent to which the interpretation of the constitution using the original intent method is able to find justice in the constitution. 


\section{Research Methods}

This study uses a doctrinal approach or also referred to as the normative legal approach (Soetandyo Wignjosoebroto, 2002: 145-177). Existing data are linked to each other through library research, reviewed and interpreted also analysed to draw conclusions. Normative research methods are research that refers to legal norms contained in legislation and court decisions. Resources are obtained from literature or secondary data (Amiruddin and Zainal Asikin, 2012: 118, which consists of primary legal and secondary legal materials. Primary legal materials include basic norms or rules, namely the 1945 Constitution, laws and regulations also decisions of the Constitutional Court in the case of testing legal norms. Secondary legal materials are documents other than legal products that provide additional information on primary legal materials. Those legal materials may include constitutional interpretation literature, research results, legal expert opinions and scientific articles related to interpretation in the Constitutional Court's decision. The data obtained will be analysed by qualitative descriptive methods.

\section{Research Result and Discussion}

\section{A. Basic Postulates in the Interpretation of the Constitution}

The interpretation of the constitution or "constitutional interpretation", is being differently understood by Albert $\mathrm{H}$. Y. Chen who states that the "constitutional interpretation" is different from "interpretation of statues" (Albert H.Y. Chen, 2000: 1-2). Interpretation of the constitution is an interpretation of the provisions contained in the constitution, or can be referred to as "interpretation of the Basic Law". The interpretation of the constitution is essentially the core of the constitutional assessment process for a law because when the constitutional judges, examine and decide cases of judicial review, they must use constitutional provisions as a touchstone. This has happened since 1803 at the United States judicial review case Marbury v Madison.

The judicial review, instituted by the judiciary body, gives magistrates the authority to investigate and evaluate the content of the laws that constitute their testing ground. When a law in its entirety is either complied or stated not complied to its higher degree of law by the agency responsible for its interpretation, therefore, process has been subjected to interpretation or according to Rosjidi Ranggawidjaja (Tanto Lailam, 2014: 92), that the process has been included in the process of discovering and expounding the meaning of the articles of law and the constitution.

The Constitutional Court (MK) as the guardian of the constitution based on Article $24 \mathrm{C}$ of the 1945 Constitution has 4 authorities, including:

1. Testing the law against the 1945 Constitution 
2. Disputes of authority between state institutions

3. Dissolution of political parties

4. Disputed election results and deciding the opinion of the DPR in the process of impeaching the President and Vice President.

Acting as a judicial institution which examines, decides and adjudicates cases, The Constitutional Court must interpret constitution as one of the methods of legal discovery. One of the characteristics of Constitutional Court's decision is that it will be final and binding which means that the Constitutional Court's decision is a decision at the first and last level. Constitutional interpretation can, in fact, be done by anyone, but the institution that can decide the interpretation of the constitution is the Constitutional Court, so that the Constitutional Court functions as the "final interpreter of the constitution."

Interpretation is one of the methods in law finding (rechtvinding), according to Sudikno Mertokusomo, this method is a means or tool to find out the meaning contained in law (Tanto Lailam, 2014: 92). Upon deciding on a case, the Constitutional Court will use interpretation of the constitution as a method of legal discovery. Based on Article 5 paragraph (1) of the Law on Judicial Power,

"Judges and constitutional judges must explore, follow and understand the legal values and a sense of justice that lives in society."

The interpretation of constitution made by $\mathrm{MK}$, in its core, should contain justice in accordance with the Pancasila on the $5^{\text {th }}$ norm, Social Justice for All Indonesian people. Justice in accordance to constitution is no longer mean justice by various parties, thus, MK as the last institution to interpret the constitution must be free from political elements and interests.

Based on the living constitution theory, the 1945 Constitution of the Republic of Indonesia must be understood as a constitution that has textual and contextual dynamics. The constitutional interpretation carried out by the Constitutional Court as the final interpreting institution of the constitution is vulnerable from abuse of authority. Thus, the judges' responsibility for the interpretation methods, freedom and independence in interpreting the constitution must subject to be held to public and academic responsibility (Satriawan, Iwan, 2008). There is an adage: to read the law is to interpret the law (Feri Amsari, 2011: 180), that the legal text is clearly a way for lawmakers to act pragmatically while secretly acknowledging when it is difficult to provide an explanation. The authority of the Constitutional Court in interpreting the constitution is superior, and is vulnerable to subjective thinking.

Keith E. Whittington divides two ways to understand the constitution, namely by interpreting the constitution that aims to find the meaning of the constitutional text and the construction of the constitution that aims at political interpretation when the interpretation of the constitutional text cannot ensure a hint of activity or action

\begin{tabular}{lll|l|l}
\hline Yustisia Volume 9 Number 3 (September-December 2020) & Constitutional Interpretation of Original ... & 352
\end{tabular} 
(Harjono, 2008: 407). The purpose of interpreting the constitution literally is to find meaning and to elaborate on current developments.

\section{B. Original Understanding of Original Intent}

In general, the pattern of constitution interpretation is divided into two, namely original intent and non-original intent, or also can be called textual meaning (originalis) or contextual meaning (non-originalis). The originalist group are likened to the adherents of understanding legal positivism and the non-originalist as the adherents of progressive understanding (Pusat Studi Konstitusi FH Andalas, 2010: 153). Both led to endless academic debates to this day. The American Supreme Judge, who adheres to the originalist genre, Antonin Scalia, argues that, the interpretation of the text as a form of constitutional interpretation that is closest to the original meaning of the Constitution and is least susceptible to political influence.

The living constitution theory known In state constitutional law has been known as one of the judges' ways to find law or interpretation. Constitutional Interpretation by the original method is intended as an answer to the looseness of the living constitution theory in interpreting texts (Catherine L. Langford, 2017: 10). The Constitutional Justice of the Republic of Indonesia, I Dewa Gede Palguna, explained the strong reasons for originalist interpretation as the most appropriate interpretation in understanding the constitution as well as the basis for determining conflicting legal norms, including (I Dewa Gede Palguna, 2013: 289):

1. Originalism suppresses the possibility that unelected judges will seize power from elected people's representatives;

2. On the long run, originalism gives court authorities better protection;

3. Non originalism gives judges too much space to impose their own values which are subjective and elitist, judges need neutral and objective criteria to produce valid decisions, neutral criteria are given by the understanding of the designers (of the law) and those who ratified the constitution clause;

4. Originalism gives better respect to understanding the constitution as a binding contract;

5. Originalism more often forced lawmakers to reconsider and possibly change bad laws of their own making rather than allowing courts to cross out laws.

This originalist interpretation focuses on evaluating legal norms based on original meaning or original intent. The interpretation of constitution using original intent method is being interpreted as an interpretation that steeped into the initial spirit of the formation of written constitution through debate during 1945 
Constitution preparation, constitution-drafting opinions in relation to understand the basic aims and foundations of the state.

According to Mahfud MD, MK must take original intent as a benchmark for interpreting constitution. Understanding the original intent protects the purity of the original ideas and enthusiasm of formulation of laws and regulations, as well as the constitution or the 1945 Constitution of Republic of Indonesia (Moh Mahfud MD, 2009). The very broad authority of Constitutional Court on interpreting the constitution which is complemented by the freedom and independence of judges, makes benchmarking a constitutional interpretation obscure. The Constitutional Court's verdict, which after having been decided, makes no other legal effort possible, made the verdict's accountability very crucial. An indicator of interpretation must be made without reducing the freedom of judges to decide on a case. One of the indicators or benchmarks, that is interpreting the conflicting legal norms, is has to being seen from the spirit and original intention first in the formulation of the constitution and of legislation.

\section{Social Justice in the Constitution}

Justice is one of the most discussed legal goals throughout the history of legal philosophy. According to Aristotle in the Nichomacen Ethics book, justice is a virtue related to human relations, that the word "fair" contains more than one meaning. Fair can mean according to the law and what is comparably, that is, what should be ((Dardji Darmohardjo, 2006: 1). Unfairness is being interpreted if someone takes more than their supposed to take. The term "fair" in Indonesia is better known as "social justice" in accordance with the 5th precepts of Pancasila.

Social justice is a direct mandate written in the $5^{\text {th }}$ precept of Pancasila as a national ideology. The Preamble of the 1945 Constitution on paragraph IV contains the purpose of the country ended with the sentence, "as well as to promote social justice for all Indonesians". Social justice became the vision and mission of Indonesian as a nation embodied in various forms of national order and social welfare. Later, the Law Number 6 of the year 1974 was made to enact the Social Welfare Principles which was later amended by the Social Welfare Act number 11 of 2009. This provision was borne out of the trust of the nation to be responsible for protection of all Indonesian people and to promote common good in order to create social justice for all Indonesians.

The social justice concept is different from the idea of justice in general, social justice is more emphasized on the principles of human rights and egalitarianism (Jimly Asshiddiqie, 2015: 89). An understanding of economic justice, political justice and legal justice will lead to the idea of social justice for all.

The law is a product of democracy or the product of the will of many, although it has fulfilled democratic procedures, for example, it has been approved by Parliament and the President, a law does not necessarily fulfil the voice of justice and

\begin{tabular}{lll|l|l|l}
\hline Yustisia Volume 9 Number 3 (September-December 2020) & Constitutional Interpretation of Original ... & 354
\end{tabular} 
constitutional truth. The majority vote is not identical with the justice and constitutional truth. If it contradicts the 1945 Constitution as a basic law and written constitution, then a law can be declared not generally binding. Although only approved by 5 out of 9 judges of the Constitutional Court. Through this constitutional court, the 1945 Constitution is truly being enforced in practical state administration.

The constitution was formed based on an initial understanding of general ideology, social conditions and objectives to achieve. Pancasila becomes the crystallization of national ideology from the various dialectical processes that underlie every article and text in the constitution. The agreed constitution became a guideline for the formation of national legal system.

The word "just" in NRI Constitution of 1945 Preamble were repeated 5 times, whereas in the body contained in Article 7B paragraph (4), Article 9 paragraph (1), Article 18A paragraph (2), Article 22E paragraph (1), Article 24 paragraph (1), Article 24A paragraph (2), Article 24C paragraph (5), Article 28D paragraph (1 and 2), Article $28 \mathrm{H}$ paragraph (2), Article 28J paragraph (2), and Article 33 paragraph (3) of the NRI Constitution 1945.

Justice theorists explain that welfare can be very rarely distributed equally, so that, in the end, there will always be a group that benefits more from a surplus being distributed (Shidarta, 2015: 34). This situation often creates social disparities that cannot be resolved simply by including the word "fair" in the legislation text. The role of law enforcement becomes important to uphold justice which, in practice, experiences a shift in meaning. Social disparity that occurs becomes a challenge for law enforcers to return to the ideal order of a conducive social structure.

Justice in one particular country is marked by political openness on the government part in the legal process based on justice rules. The role of a people's legitimacy based sovereign government responsibility is to maintain the stability and integrity of social structure as a whole.

According to Jimly Asshidiqie, constitution divides into three parts; political constitution; economic constitution and social (cultural) constitution (Jimly Asshidiqie, 2008: 23). The substantial position of constitution as a ground norm in Indonesia has not only being related to the practice of state administration, but also the life of the land and nation. Politics, economics and social culture are the substance of constitution based on the principle of justice. While the role of constitution can be reduced by government discretion, the importance of constitution in a country as a basic norm should not be ruled out.

The suboptimal role of law enforcement will create weakness of justice within the law itself. Carrying out constitutional mandate and opening up political and legal process, will increase people's trust in a sense of justice. Public appreciation for government goodwill in governing will strengthen the social structure that will run 
between the formulation of aspirations, regulations, implementation and law enforcement.

There has not been uniformity parameters for implementing justice in the constitution yet. In Indonesia, by using basic norms from written constitution such as the 1945 Constitution, directs some legal experts to positivist order. Positivist groups direct that justice must be held in accordance with the text mandated in the written constitution or the 1945 Constitution. This group puts forward many originalist interpretations in the constitution. Finding justice is at the level of compatibility between the implementation of mandate and the initial intention of what is formulated into constitutional text.

\section{Understanding the Constitutional Text in Judicial Review}

Based on research conducted by constitutional expert M. Ali Safaat, having trough decisions of the Constitutional Court for the period 2003 - 2008 and the period 2009 - 2013, not all legal decision made by Constitutional Court's in the case of judicial review of the 1945 Constitution provide an interpretation as provisioned by 1945 Constitution which supposed to be a touchstone (M. Ali Safaat, 2017: 260). The interpretation method used by general is the originalist interpretation, the most widely used is the structural or functional interpretation and original intent as well as some that use non-originalist interpretation with a doctrinal approach or ethical approach.

Other research related to testing the law in the Constitutional Court's decision is found in the study of Andalas University's constitutional study center (Pusat Kajian Konstitusi Fak. Hukum Universitas Andalas, 2010: 211-212). The Constitutional Court's decisions changed, at first the Constitutional Court often merely protected the sound of the provisions of the 1945 Constitution, but in its development, the Court also tried to complement the generally accepted laws. The Court began a profound interpretation in upholding substantive justice. However, this study also provides recommendations in overcoming mistakes over weaknesses as humans. Consistency in interpreting decisions, between progressive interpretations, then turns into very textual thinking as a measurement tool for the community towards constitutional justices.

Another view is given by Pan Moh. Faiz, that the practice of judicial activism has actually been carried out by the Constitutional Court in several of its decisions. These decisions often invite political debate rather than academics. The practice of judicial activism is no longer taboo in other developed countries, the constitutional text must be seen as a living norm (Pan Moh. Faiz, 20116: 245). If judges are being limited in their interpretation, constitutional texts are not to be recognized as living organisms and are becoming obsolete in an increasingly dynamic age.

\begin{tabular}{lll|l|l|l}
\hline Yustisia Volume 9 Number 3 (September-December 2020) & Constitutional Interpretation of Original ... & 356
\end{tabular} 
Based on conducted academic studies, the Court has made various interpretations using the original intent as part of the originalist group. However, there are also decisions that are considered to be progressive and are not always based on textual perspective.

Testing the law is a way to test suitability of the meaning of the law with the 1945 Constitution, or it can also be said, to test the constitutionality of the norm. Every law tested must be able to choose an article in the 1945 Constitution which then be used as a touchstone. Constitutional or unconstitutional is the result of interpretation from constitutional judges in deciding a case for judicial review. The 1945 Constitution has the authority to delegate various rules into the legislation below. The constitution, as a source of law in its underneath regulations, is philosophically stated that no law appears without a constitutional order. Differ on the practices development, the delegation of the constitution has various indicators, respectively.

In his dissertation entitled "Development of Delegation Regulations in Indonesia", Muhammad Fadli stated that the requirement for the delegation of authority was to state explicitly (Mohammad Fadli, 2012: 42):

1. The scope of the material content being arranged; and

2. The form of regulations.

If the delegated content has been partially regulated in part in the delegating laws and regulations, but the content may only be regulated in the legislation that is being delegated and does not contain sub-delegations, the must use sentence is: "Further provisions regarding ... regulated by ... ". The 1945 constitutional test stone is important for mapping the constitutionality of a law or article in a law. Article tested in the 1945 Constitution must also have a connection with the law or article in the law being tested.

\section{Freedom of Constitutional Justices in Interpretation}

Based on article 5 of the Judicial Power Law that judges have the authority to interpret and explore values in society. The principle of independence is one thing that must be upheld in respecting each court decision. Constitutional Justices have considerable authority in formulating various interpretations in each decision.

This authority is susceptible to various interests, Akil Mochtar and Patrialis Akbar being one of the cases within the Constitutional Court which has been proven that great authority or power does not always have a positive impact. State power that is born with negative talent. As Lord Acton said, "power tends to corrupt absolute power is corrupt absolutely".

The judges' independence and freedom in interpreting the law cannot be said to be free without limits (Kukuh Tejomurti, 2019: 277). The limitation of the freedom of judges in interpreting is the Pancasila and the 1945 Constitution of the Republic of Indonesia (Sapto Hermawan, 2019), that any verdicts must not in contradict to

\begin{tabular}{lll|l|l|l}
\hline Yustisia Volume 9 Number 3 (September-December 2020) & Constitutional Interpretation of Original ... & 357
\end{tabular} 
Pancasila and the 1945 Constitution of the Republic of Indonesia. However, nine judges who guarded the constitution with great powers should still have oversight and accountability.

The inconsistency of the Constitutional Court's decision was also can be seen in the dualism of the Constitutional Court's interpretation related to the interpretation of the offense of insult, defamation and defamation of state officials other than the President and Vice President. In the decision Numbered 013-022 / PUU-IV / 2006, the Court emphasized that the prosecution of insults should be based on complaints. This interpretation implicitly emphasizes the material aspects of Article 207 of Law Number 1 of 1946 concerning the Criminal Code (KUHP). This also happened in Article 160 of the Indonesian Criminal Code concerning sedition as outlined in the Constitutional Court Decision Number 7 / PUU-VII / 2009. However, in Decision Number 014 / PUU-VI / 2008, the Constitutional Court opinion was that the protection of state officials who were carrying out public duties, implicitly emphasized the formal aspects of the Article. Apart from the flexibility of Article 207, these two different interpretations raise separate questions related to the consistency of the Constitutional Court in distinguishing between insults aimed at state officials with insults to their personal capacity (Setara Institute, 2013: 19-20).

Constitutional judges have freedom in interpretation, but constitutional judges must also be able to interpret consistently. The Constitutional Court's decision, which was final and binding, and was only escorted by nine constitutional judges with judicial review tested in 37 Article of the 1945 Constitution, made the scope of the constitutional judge to decide smaller. Inconsistencies in the Constitutional Court's decision will be easily visible and create legal uncertainty in Indonesia.

The Constitutional Court's decision can become a reference for the constitutional judge in deciding, the meaning of "Right to Control the State" has been tested three times and have commonality of the verdicts. This means that if the Constitutional Court is consistent, even being tested for hundreds of times, the meaning of the right to control the state will be the same, but if it is based on the principle of independence of judges, there is no prohibition on constitutional judges making different decisions. In this situation, an idea is needed to encourage the Constitutional Court to become a more professional institution by building a system of accountability for the Constitutional Court publicly and academically in every interpretation in its decision.

\section{Conclusion}

1. Interpretation using original intent is one of the interpretations in the originalist group. This originalist interpretation focuses on evaluating legal norms based on original meaning. The 1945 Constitution as a basic norm, made in the basic framework of Pancasila as a fundamental norm staat. The Indonesian 
Constitution is the basis of legal sources that are considered to have shared values of justice. Textual interpretation in testing the law has a simple definition in looking for the meaning of justice, which adjusts the meaning of the law with what is wanted by the 1945 Constitution. If it is different, it is unconstitutional and when it is suitable, it is constitutional. However, believing that the 1945 Constitution is a sacred norm and certainly has the truth to make the text in the constitution as a non-living organism, while the dynamics of the law continues to develop. This making that dynamic vulnerable to the shift in the meaning of justice in accordance with Article 5 of the Judicial Power Law, judges are allowed to explore a sense of justice in the community if it is not found in the text.

2. Judges have independence in deciding cases, no intervention from any party when the judge formulates a decision. The freedom of judges to decide is not freedom without limits. The limitations of judges' freedom of interpretation are Pancasila and the 1945 Constitution. Decisions made by judges must not conflict with Pancasila and the 1945 Constitution, constitutional judges have great power in interpreting the 1945 Constitution. This power is vulnerable to various interests which make the decisions of constitutional judges not objective. Accountability of decisions in public and academics should be a legal idea that can be realized, not to judge the verdict but to know the basis of interpretation and or legal discovery by constitutional judges.

\section{BIBLIOGRAPHY: \\ Books:}

Amiruddin and Zainal Asikin. (2012). Pengantar Metode Penelitian Hukum. Rajawali Pers: Jakarta.

CF. Strong. (2012). Modern Political Constitution, Nusa Media: Bandung.

David Dyzenhaus. (2016). Philosophical Foundations of Constitutional Law. Oxford University Press.

Jimly Asshiddiqie. (2015). Gagasan Konstitusi Sosial. Jakarta: LP3ES.

Jimly Asshidiqie. (2008). Ekonomi Konstitusi. Kompas Gramedia: Jakarta.

KC. Wheare. (2008). Konstitusi-Kontitusi Modern, Terjemahan. Nusa Media: Bandung.

Maria Farida Indrati, dalam pidato purna bakti FH UI, Eksistensi Penjelasan UUD 1945 setelah amandemen, Depok 26 September 2019. 
Miriam Budiardjo. (2008). Dasar-Dasar Ilmu Politik. PT. Gramedia: Jakarta.

Mohammad Fadli, "Perkembangan Peraturan Delegasi di Indonesia", Disertasi pada Program Doktor Ilmu Hukum Fakultas Hukum Universitas Padjajaran, Oktober (Bandung: Universitas Padjajaran, 2012).

Saldi Isra. (2010). Pergeseran Fungsi Legislasi: Menguatnya Model Legislasi Parlementer dalam Sistem Presidensial Indonesia. Rajawali Press: Jakarta.

Soetandyo Wignjosoebroto. (2002). Hukum: Paradigma, Metode dan Dinamika Masalahnya. Huma: Jakarta.

Setara Institute. (2013). “Ringkasan Laporan Riset 10 Tahun Kinerja Mahkamah Konsitusi; Mahkamah Konstitusi Sebagai Mekanisme Nasional Baru Hak Asasi Manusia". Setara Institute: Jakarta.

\section{Journals:}

Albert H.Y. Chen. (2000). The Interpretation of Basic Law-Common Law and mainland Chinese Perspective, Hong Kong: Hong Kong Journal Ltd.

H. Jefferson Powel. (1980). The Original Outstanding of Original Intent, Harvard Law Review Vol. 98 No. 5.

Jimly Asshiddiqie. (2002). Ideologi, Pancasila dan Konstitusi, Mahkamah Konstitusi: Jakarta.

Jose Juan Moreso. (1998). Legal Indeterminacy and Constitutional Interpretation, Law and Philosophy Journal Vol. 37.

Manthovani, R., \& Tejomurti, K. (2019). A HOLISTIC APPROACH OF AMNESTY APPLICATION FOR BAIQ NURIL MAKNUN IN THE FRAMEWORK OF CONSTITUTIONAL LAW OF INDONESIA. Yustisia Jurnal Hukum, 8(2), 277-291.

M. Ali Safaat, et.al. (2017). Pola Penafsiran Konstitusi dalam Putusan MK Periode 2003-2008 dan 2009-2013, Jurnal Konstitusi Vol. 14 No. 2.

Pusat Kajian Konstitusi Fak. Hukum Universitas Andalas. (2010). Perkembangan Pengujian Perundang-undangan di Mahkamah Konstitusi, Jurnal Konstitusi Vol. 7 No. 6 Desember 2010.

Pan Moh. Faiz. (2016). Dimensi Judicial Activism dalam Putusn Mahkamah Konstitusi, Jurnal Konstitusi, Vol. 13 No. 2. 
Hermawan, S. (2019, October). Law and Economic Approach to Reduce Marine Plastic Litter in Indonesia. In 3rd International Conference on Globalization of Law and Local Wisdom (ICGLOW 2019). Atlantis Press.

Shidarta. (2015). Membaca Ulang Pemaknaan Keadilan Sosial Dalam Gagasan Revolusi Hukum Soediman Kartohadiprodjo, Jurnal Veritas et Justitia, Volume 1 No. 1.

Tanto Lailam. (2014). Penafsiran Konstitusi dalam Pengujian Konstitusionalitas Undang-undang Terhadap UUD 1945, Jurnal Media Hukum Vol. 21. 